\title{
KETERAMPILAN MENULIS CERITA FANTASI BERDASARKAN KOMIK "DORAEMON" PESERTA DIDIK KELAS VII-I MTSN 2 KOTA BANJARMASIN
}

\section{FANTASY STORY WRITING SKILLS BASED ON COMICS "DORAEMON" STUDENT CLASS VII-I MTSN 2 KOTA BANJARMASIN}

\author{
Rizka Khairunnisa; Noor Cahaya; Ahsani Taqwiem \\ Program Studi Pendidikan Bahasa dan Sastra Indonesia \\ FKIP Universitas Lambung Mangkurat \\ rizka0373@gmail.com
}

\begin{abstract}
Abstrak
Penelitian ini bertujuan untuk mendeskripsikan keterampilan menulis cerita fantasi berdasarkan komik "Doraemon" peserta didik kelas VII-I MTsN 2 Kota Banjarmasin berdasarkan unsur pembangun dan ciri kebahasaan cerita fantasi. Unsur pembangun cerita fantasi tersebut yaitu tema, tokoh, latar, alur, sudut pandang, dan amanat. Pada penelitian ini menggunakan metode deskriptif dengan pendekatan kualitatif. Berdasarkan seluruh aspek yang telah diteliti, seluruh peserta didik tergolong terampil pada aspek tokoh, alur, dan sudut pandang. Peserta didik kelas VII-I MTsN 2 Kota Banjarmasin yang tergolong terampil berjumlah $10,71 \%$. Peserta didik yang tergolong mampu berjumlah 64,29\%. Peserta didik yang tergolong cukup terampil berjumlah $21,43 \%$. Peserta didik yang tergolong kurang terampil berjumlah 3,57\%.
\end{abstract}

Kata kunci: keterampilan menulis, cerita fantasi, komik Doraemon

\begin{abstract}
This study aims to describe the skills of writing fantasy stories based on the comic "Doraemon" students of class VII-I MTsN 2 Kota Banjarmasin based on the building elements and linguistic characteristics of fantasy stories. The elements of the fantasy story builder are theme, character, setting, plot, point of view, and message. In this study using a descriptive method with a qualitative approach. Based on all aspects that have been studied, all students are classified as skilled in the aspects of characters, plot, and point of view. Students of class VII-I MTsN 2 Kota Banjarmasin are classified as skilled at $10.71 \%$. Students who are classified as capable amounted to $64.29 \% .21 .43 \%$ students were classified as quite skilled. Students classified as less skilled amounted to $3.57 \%$. Keywords: writing skills, fantasy stories, Doraemon comics
\end{abstract}

\section{Pendahuluan}

Kenyataan bahwa masih banyak peserta didik yang kesulitan dalam menulis sebuah cerita dengan baik banyak ditemukan di sekolah. Hal tersebut dapat dibuktikan dari artikel yang ditulis oleh Saputra, Sutama, dan Gunatama (2017) dengan judul "Penggunaan Video Anak Pertualangan Alice di Negeri Ajaib untuk Meningkatkan Kemampuan Menulis Cerita Fantasi di
Kelas VII H SMP Negeri 2 Sawan”. Pada penelitian tersebut skor rata-rata menulis peserta didik sebesar 68,83 , sedangkan skor yang harus dicapai minimal adalah 75 . Hal ini terkait dengan bacaan mereka yang sedikit atau kurangnya pemahaman dalam membaca suatu teks.

Berdasarkan penyataan tersebut, menulis sebuah cerita fantasi merupakan suatu yang dianggap sulit. Padahal, dalam 
Pelajaran Bahasa Indonesia Kurikulum 2013, terdapat kompetensi dasar yang menyatakan bahwa peserta didik mampu menyajikan sebuah cerita fantasi. Kompetensi dasarnya yaitu 4.4 menyajikan gagasan kreatif dalam bentuk cerita fantasi secara lisan dan tulis dengan memperhatikan struktur dan penggunaan bahasa.

Irwansyah (dalam Liputan 6: 2014) menyatakan bahwa film Doraemon yang berjudul Stand by Me Doraemon di bioskop sejak tayang tujuh hari sudah mampu mendatangkan 450 ribu penonton. Pernyataan tersebut membuktikan bahwa banyak orang yang sudah mengetahui tokoh Doraemon dan banyak orang yang tertarik terhadap Doraemon.

Alasan lain yang menguatkan penggunaan media komik Doraemon dalam pembelajaran menulis cerita fantasi yaitu cerita Doremon merupakan cerita fantasi. Hal tersebut dikarenakan tokoh Doraemon merupakan seekor kucing yang memiliki alat super yaitu kantong ajaib. Latar yang diambil dalam kisah Doraemon bisa memuat dua latar yaitu latar di bumi dan latar yang tidak dapat ditinggali oleh manusia biasa.

Pada penelitian Nurbaya (2016) peneliti sudah pernah menggunakan media komik, tetapi yang diamati adalah peserta didik SD dalam hal menulis sebuah karangan narasi. Sedangkan, pada penelitian ini yang diamati adalah peserta didik kelas VII-I MTsN dalam hal membuat sebuah cerita fantasi. Selain itu, tempat penelitian pada penelitian ini juga berbeda, yaitu di MTsN 2 Kota Banjarmasin.

Dari uraian di atas, masalah yang dibahas yaitu bagaimana keterampilan menulis cerita fantasi berdasarkan komik "Doraemon" peserta didik kelas VII-I MTsN 2 Kota Banjarmasin. Tujuan penelitian ini yaitu untuk mendeskripsikan keterampilan menulis cerita fantasi berdasarkan komik "Doraemon" peserta didik kelas VII-I MTsN 2 Kota Banjarmasin.

\section{Metode Penelitian}

\section{Jenis Penelitian}

Deskriptif kualitatif merupakan jenis penelitian ini. Metode yang dipakai merupakan metode deskriptif dengan pendekatan kualitatif.

\section{Waktu dan Tempat Penelitian}

Penelitian ini dilakukan selama dua bulan. Penelitian bertempat di MTsN 2 Kota Banjarmasin.

\section{Subjek Penelitian}

Penelitian ini meneliti peserta didik kelas VII-I MTsN 2 Kota Banjarmasin yang berjumlah 28 orang sebagai subjek penelitian. Kelas VII-I dipilih karena hasil obeservasi peneliti. Peserta didik di kelas 
tersebut lebih banyak menyukai membaca komik Doraemon daripada menontonnya di televisi. Pada kelas lainnya, peserta didik yang membaca komik Doraemon dapat dikatakan lebih sedikit, mereka hanya menonton Doraemon di televisi.

\section{Prosedur}

Pada penelitian ini, peneliti melakukan observasi di sepuluh kelas VII MTsN 2 Kota Banjarmasin untuk mengetahui pengetahuan mereka mengenai tokoh Doraemon dan teman-temannya. Selanjutnya, peneliti merekam proses pembelajaran peserta didik untuk memastikan tidak ada yang mencontek. Tahap terakhir, yaitu peneliti melakukan tes kepada peserta didik kelas VII-I MTsN 2 Kota Banjarmasin. Peserta didik diminta untuk menulis sebuah cerita fantasi berdasarkan komik Doraemon yang berjudul Rumah Semakin Jauh karya Fujiko F. Fujio.

\section{Data, Instrumen, dan Teknik Pengumpulan Data}

Data pada penelitian ini adalah hasil tulisan cerita fantasi peserta didik. Data tersebut diperoleh dari hasil tes tertulis peserta didik. Instrumen yang digunakan sebagai sarana pengumpulan data yaitu tes dan buku komik Doraemon. Untuk kriteria keterampilan menulis cerita fantasi disesuaikan dengan unsur pembangun dan ciri kebahasaan cerita fantasi. Peneliti mengumpulkan data dengan observasi, rekam, dan tes.

\section{Teknik Analisis Data}

Teknik analisis data dalam penelitian ini dilakukan dalam beberapa cara yaitu (a) peneliti mengamati proses pembelajaran peserta didik pada materi cerita fantasi; (b) kemudian, peneliti melakukan tes kepada peserta didik yang berupa menulis sebuah cerita fantasi berdasarkan komik Doraemon yang dibacanya. Berdasarkan data berupa hasil karangan peserta didik, peneliti akan menganalisis cara penggambaran tema, tokoh, latar, alur, sudut pandang, amanat dan ciri kebahasaan; (c) dari hasil penganalisisan tersebut, peneliti akan mendeskripsikan satu per satu dan menarik kesimpulan. Setelah menarik kesimpulan, digunakan persentase untuk memudahkan peneliti dalam menghitung hasil keterampilan peserta didik. Persentase dihitung dengan rumus dari Rukajat (2018:91).

$$
p=\frac{f}{n} \times 100 \%
$$

Keterangan:

$\mathrm{p}=$ Angka persentase

$\mathrm{f}=$ Frekuensi yang dicari persentasenya

$\mathrm{n}=$ Jumlah anak dalam satu kelas

$$
\text { Variabel yang diamati dalam }
$$
penelitian yaitu keterampilan peserta didik 
dalam menulis sebuah cerita fantasi berdasarkan komik yang dibaca. Aspekaspek yang akan dideskripsikan dalam penelitian ini seperti, (a) cara penggambaran tema, (b) cara penggambaran tokoh, (c) cara penggambaran latar, (d) cara penggambaran alur, (e) pemakaian sudut pandang (f) cara penggambaran amanat, (g) penggunaan ciri kebahasaan.

\section{Kriteria Keterampilan}

\section{Menulis Cerita Fantasi}

Pada tabel di bawah ini, setiap aspek memiliki empat indikator. Dari setiap indikator yang sudah tercapai akan diberi contreng $(\sqrt{ })$ di kolom ketercapaian. Peserta didik yang sudah memuat keempat indikator dikategorikan terampil. Peserta didik yang memuat tiga indikator dikategorikan cukup terampil. Peserta didik yang memuat dua indikator dikategorikan kurang terampil.
Tabel 1. Kriteria Keterampilan Menulis Cerita Fantasi Berdasarkan Komik "Doraemon"

Nama: ....

Kelas: ....

\begin{tabular}{|c|c|c|c|c|c|c|}
\hline $\mathrm{N}_{0}$ & Aspek & Indikator & & capai & & Keterangan \\
\hline & & & \begin{tabular}{l|l|}
1 & 2 \\
\end{tabular} & 3 & 4 & \\
\hline 1. & Tema & $\begin{array}{l}\text { Kesesuaian tema yang digambarkan } \\
\text { peserta didik dengan yang ada di dalam } \\
\text { cerita, kesesuaian dengan ide pokok } \\
\text { cerita, kreativitas peserta didik dalam } \\
\text { menggambarkan tema yaitu menarik } \\
\text { dan unik. }\end{array}$ & & & & \\
\hline 2. & Tokoh & $\begin{array}{l}\text { Kesesuaian tokoh yang digambarkan } \\
\text { peserta didik dengan yang ada di komik, } \\
\text { kerincian deskripsi tokoh, kesesuaian } \\
\text { watak tokoh, dan kreativitas dalam } \\
\text { menggambarkan tokoh yaitu merupakan } \\
\text { tokoh yang unik/tidak nyata. }\end{array}$ & & & & \\
\hline 3. & Latar & $\begin{array}{l}\text { Latar yang dimuat pada karangan ada } \\
\text { tiga, kejelasan dan kerincian } \\
\text { menggambarkan latar, dan kreativitas } \\
\text { dalam menggambarkan latar. }\end{array}$ & & & & \\
\hline 4. & Alur & $\begin{array}{l}\text { Kreativitas mereka dalam } \\
\text { penggambaran alur yaitu lengkap, } \\
\text { kreatif dan kompleks, kejadian } \\
\text { mengandung hukum sebab akibat, dan } \\
\text { urutan dalam penggambaran alur. }\end{array}$ & & & & · \\
\hline 5. & $\begin{array}{c}\text { Sudut } \\
\text { Pandang }\end{array}$ & $\begin{array}{l}\text { Pemakaian sudut pandang, kesesuaian } \\
\text { dengan cerita, sudut pandang yang tidak } \\
\text { berubah-ubah, menggunakan kata ganti } \\
\text { yang sesuai. }\end{array}$ & & & & \\
\hline 6. & Amanat & $\begin{array}{l}\text { Kreativitas peserta didik menyampaikan } \\
\text { amanat yang telah mereka dapat dari } \\
\text { komik ke dalam karangan yang } \\
\text { dikembangkan, amanat yang } \\
\text { dikembangkan mengandung pesan yang } \\
\text { ada pada karangan, amanat mengandung } \\
\text { makna. }\end{array}$ & & & & \\
\hline
\end{tabular}




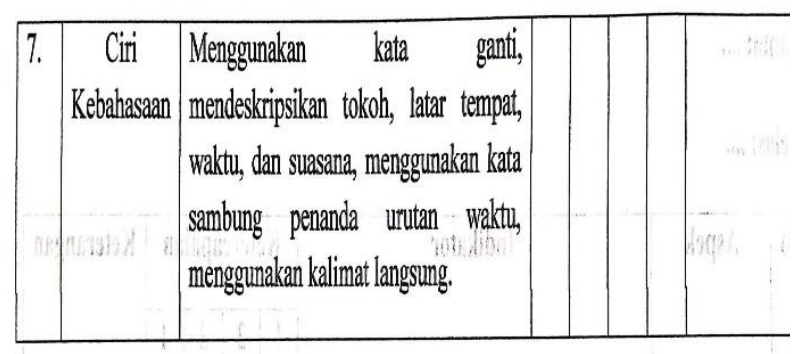

Gambar 1. Kriteria Keterampilan Menulis Cerita Fantasi Berdasarkan Komik Doraemon

\section{Hasil Penelitian dan Pembahasan}

Pada bagian hasil penelitian dan pembahasan ini akan dijelaskan hasil penelitian secara rinci mengenai Keterampilan Menulis Cerita Fantasi Berdasarkan Komik "Doraemon" Peserta Didik Kelas VII-I MTsN 2 Kota Banjarmasin. Berikut hasil penelitian dan pembahasan.

\section{Hasil Penelitian}

Pada bulan Oktober 2019, peneliti melakukan kegiatan observasi terlebih dahulu. Kegiatan observasi dilakukan kepada peserta didik kelas VII-I MTsN 2 Kota Banjarmasin untuk mengetahui tentang pembelajaran peserta didik dalam menulis sebuah karangan dan pengetahuan mereka mengenai tokoh Doraemon. Setelah melakukan observasi, peneliti melakukan kegiatan tes. Kegiatan tes dilakukan pada tanggal 4 November 2019. Kegiatan tes dilakukan untuk mengetahui keterampilan peserta didik dalam menulis cerita.
Kegiatan tes dilakukan bersamaan dengan kegiatan rekam.

\section{Pembahasan}

\section{Tema}

Kriteria terampil dalam penulisan tema yaitu kesesuaian tema yang digambarkan peserta didik dengan yang ada di dalam cerita, dan kreativitas peserta didik dalam menggambarkan tema yaitu menarik, unik, dan inspiratif. Dari 28 peserta didik, 25 orang peserta didik sudah terampil mengembangkan tema dari cerita yang dikembangkannya. Hal terssebut dapat dilihat pada tabel berikut.

Tabel 2. Hasil Keterampilan Menulis Cerita Fantasi Pada Aspek Tema

\begin{tabular}{|c|c|c|}
\hline Kategori & Jumlah & Persentase \\
\hline Terampil & 25 orang & $89,29 \%$ \\
\hline $\begin{array}{c}\text { Cukup } \\
\text { Terampil }\end{array}$ & 2 orang & $7,14 \%$ \\
\hline $\begin{array}{c}\text { Kurang } \\
\text { Terampil }\end{array}$ & 1 orang & $3,57 \%$ \\
\hline Jumlah & $\mathbf{2 8}$ orang & $\mathbf{1 0 0 \%}$ \\
\hline
\end{tabular}

\section{Tokoh}

Ada beberapa macam kriteria terampil dalam penulisan tokoh di penelitian ini. Kriteria tersebut di antaranya kesesuaian tokoh yang digambarkan peserta didik dengan yang ada di komik, kreativitas dalam mengembangkan tokoh, kerincian deskripsi tokoh, kesesuaian watak 
tokoh, dan kreativitas dalam menggambarkan tokoh yaitu merupakan tokoh yang unik/tidak nyata dan memiliki keanehan. Peserta didik diminta untuk mengembangkan tokoh pada karangan dengan kreativitas mereka. Peserta didik dikatakan terampil jika kriteria di atas sudah terpenuhi.

Peneliti mendapatkan hasil setelah menganalisis karangan peserta didik yang berjumlah 28 karangan. Dari 28 karangan peserta didik, dapat dilihat bahwa semua peserta didik sudah terampil dalam mengembangkan tokoh. Berdasarkan keterangan tersebut, keterampilan peserta didik kelas VII-I MTsN 2 Kota Banjarmasin berdasarkan aspek tokoh berjumlah $100 \%$.

\section{Latar}

Kriteria terampil dalam menulis latar pada penelitian ini yaitu kesesuaian latar tempat, waktu dan suasana yang digambarkan peserta didik dengan yang ada di komik, kreativitas dalam mengembangkan latar, dan kejelasan serta kerincian menggambarkan latar.

Dari 28 karangan yang dihasilkan oleh 28 peserta didik kelas VII-I MTsN 2 Kota Banjarmasin, 25 orang peserta didik sudah dikatakan terampil. Akan tetapi, terdapat 2 karangan peserta didik yang dinyatakan cukup terampil. Ada juga 1 karangan peserta didik yang dinyatakan kurang terampil.

Tabel 3. Hasil Keterampilan Menulis Cerita Fantasi Pada Aspek Latar

\begin{tabular}{|c|c|c|}
\hline Kategori & Jumlah & Persentase \\
\hline Terampil & 25 orang & $89,29 \%$ \\
\hline $\begin{array}{c}\text { Cukup } \\
\text { Terampil }\end{array}$ & 2 orang & $7,14 \%$ \\
\hline $\begin{array}{c}\text { Kurang } \\
\text { Terampil }\end{array}$ & 1 orang & $3,57 \%$ \\
\hline Jumlah & $\mathbf{2 8}$ orang & $\mathbf{1 0 0 \%}$ \\
\hline
\end{tabular}

\section{Alur}

Ada beberapa kriteria terampil dalam penulisan alur di penelitian ini. Kriteria tersebut yaitu kesesuaian alur yang digambarkan peserta didik dengan yang ada di dalam komik, kreativitas mereka dalam penggambaran alur yaitu lengkap, kreatif dan kompleks, dan urutan dalam penggambaran alur.

Dari 28 karangan yang ditulis oleh 28 peserta didik, semua peserta didik dikatakan terampil dalam aspek alur. Hal tersebut karena peserta didik sudah menceritakan kejadian dengan rinci pada karangannya. Alur yang digunakan oleh 28 peserta didik pada penelitian ini yaitu alur maju. Kejadian juga diceritakan secara rinci dan memuat hukum sebab akibat. Berdasarkan keterangan tersebut, peserta didik kelas VII-I MTsN 2 Kota Banjarmasin yang dikatakan terampil berjumlah $100 \%$. 


\section{Sudut Pandang}

Ada beberapa kriteria terampil dalam menulis sudut pandang pada penelitian ini. Kriteria tersebut yaitu pemakaian sudut pandang, kesesuaian dengan cerita, sudut pandang yang tidak berubah-ubah.

Pada 28 karangan dari 28 orang peserta didik, peserta didik memakai sudut pandang orang ketiga. Seluruh peserta didik sudah dapat dikatakan terampil dalam penggunaan sudut pandang. Sudut pandang yang dipakai peserta didik tidak berubah-ubah dan selalu sama sampai akhir cerita. Berdasarkan keterangan tersebut, peserta didik kelas VII-I MTsN 2 Kota Banjarmasin yang dikatakan terampil berjumlah $100 \%$.

\section{Amanat}

Pada aspek amanat, peserta didik diminta untuk menyampaikan amanat dari cerita yang dikembangkan. Amanat tersebut harus memiliki pesan dari penulis. Ada beberapa kriteria dalam menulis amanat pada penelitian ini. Kriteria tersebut yaitu kreativitas peserta didik menyampaikan amanat yang telah mereka dapat dari komik ke dalam karangan yang dikembangkan.

Dari 28 karangan peserta didik, sebagian besar peserta didik sudah dapat dikatakan terampil dalam menulis amanat. Namun, ada 1 orang peserta didik yang dinyatakan kurang terampil dan ada 1 orang peserta didik yang dinyatakan cukup terampil.

Tabel 4. Hasil Keterampilan Menulis

Cerita Fantasi Pada Aspek Amanat

\begin{tabular}{|c|c|c|}
\hline Kategori & Jumlah & Persentase \\
\hline Terampil & 26 orang & $92,86 \%$ \\
\hline $\begin{array}{c}\text { Cukup } \\
\text { Terampil }\end{array}$ & 1 orang & $3,57 \%$ \\
\hline $\begin{array}{c}\text { Kurang } \\
\text { Terampil }\end{array}$ & 1 orang & $3,57 \%$ \\
\hline Jumlah & $\mathbf{2 8}$ orang & $\mathbf{1 0 0 \%}$ \\
\hline
\end{tabular}

\section{Ciri Kebahasaan}

Pada aspek ciri kebahasaan peserta didik diminta untuk menulis sebuah cerita fantasi dengan kebahasaan yang baik sesuai dengan ciri kebahasaan cerita fantasi. Ada beberapa kriteria pada aspek ciri kebahasaan, yaitu menggunakan kata ganti, mendeskripsikan tokoh, latar tempat, waktu, dan suasana, menggunakan kata sambung penanda urutan waktu, menggunakan kalimat langsung.

Dari 28 peserta didik, 3 orang dikatakan terampil, 2 orang dikatakan kurang terampil, dan 23 orang dikatakan cukup terampil. Peserta didik dikatakan terampil, cukup terampil, dan kurang terampil berdasarkan indikator yang sudah dibuat. 
Tabel 5. Hasil Keterampilan Menulis Cerita Fantasi Pada Aspek Ciri Kebahasaan

\begin{tabular}{|c|c|c|}
\hline Kategori & Jumlah & Persentase \\
\hline Terampil & 3 orang & $10,71 \%$ \\
\hline $\begin{array}{c}\text { Cukup } \\
\text { Terampil }\end{array}$ & 23 orang & $83,14 \%$ \\
\hline $\begin{array}{c}\text { Kurang } \\
\text { Terampil }\end{array}$ & 2 orang & $7,14 \%$ \\
\hline Jumlah & $\mathbf{2 8}$ orang & $\mathbf{1 0 0 \%}$ \\
\hline
\end{tabular}

\section{Seluruh Aspek}

Dari semua aspek yang dinilai pada penelitian ini, peserta didik dibagi menjadi empat kategori.

a. Terampil, jika seluruh aspek pembangun dan ciri kebahasaan cerita fantasi sudah dikuasai peserta didik.

b. Mampu, jika seluruh aspek pembangun cerita fantasi sudah dikuasai peserta didik. Akan tetapi, ciri kebahasaan cerita fantasi belum tercapai.

c. Cukup terampil, jika peserta didik belum menguasai salah satu aspek pembangun cerita fantasi dan ciri kebahasaannya belum tercapai.

d. Kurang terampil, jika peserta didik belum menguasai dua hingga lebih aspek pembangun cerita fantasi dan ciri kebahasaannya belum tercapai.
Berdasarkan indikator di atas, peserta didik yang tergolong terampil, mampu, cukup terampil, dan kurang terampil dapat dilihat pada tabel berikut.

$\begin{array}{ccc}\text { Tabel 6. Hasil Akhir Keterampilan } \\ & \text { Menulis Cerita } & \text { Fantasi } \\ & \text { Berdasarkan } & \text { Komik } \\ & \text { "Doraemon" } & \end{array}$

\begin{tabular}{|c|c|c|}
\hline \multicolumn{3}{|c|}{ Hasil Akhir } \\
\hline Kategori & Jumlah & Persentase \\
\hline Terampil & 3 peserta didik & $10,71 \%$ \\
\hline Mampu & $\begin{array}{c}18 \text { peserta } \\
\text { didik }\end{array}$ & $64,29 \%$ \\
\hline $\begin{array}{c}\text { Cukup } \\
\text { terampil }\end{array}$ & 6 peserta didik & $21,43 \%$ \\
\hline $\begin{array}{c}\text { Kurang } \\
\text { terampil }\end{array}$ & 1 peserta didik & $3,57 \%$ \\
\hline Jumlah & $\mathbf{2 8}$ siswa & $\mathbf{1 0 0 \%}$ \\
\hline \multicolumn{2}{|c}{}
\end{tabular}

\section{Simpulan dan Saran}

\section{Simpulan}

Setelah melakukan analisis terhadap semua data dapat diambil simpulan bahwa komik Doraemon baik digunakan dalam Pembelajaran Menulis Cerita Fantasi. Penggunakan komik pada pembelajaran cerita fantasi dapat mempermudah peserta didik untuk mengkreasikan cerita mereka. Selain terbantu dengan adanya gambar-gambar yang ada di komik, peserta didik bisa merangkai kata untuk menggambarkan ekspresi tokoh dan kejadian pada cerita. Dengan adanya komik, kreativitas dan imajinasi peserta didik berkembang. 
Peserta didik menjadi tidak kesulitan lagi membuat sebuah cerita fantasi.

Berdasarkan aspek-aspek yang digunakan untuk menentukan keterampilan menulis cerita fantasi berdasarkan komik Doraemon, peserta didik sudah menguasai aspek tokoh, alur, dan sudut pandang. Pada aspek tersebut peserta didik yang dikatakan terampil berjumlah $100 \%$. Pada aspek tema, peserta didik yang dikatakan terampil berjumlah 89,28\%. Pada aspek latar, peserta didik yang dikatakan terampil berjumlah 89,28\%. Pada aspek amanat, peserta didik yang dikatakan terampil berjumlah 92,85\%. Pada aspek ciri kebahasaan, peserta didik yang dikatakan terampil berjumlah $10,71 \%$.

Berdasarkan seluruh aspek yang telah diteliti, peserta didik kelas VII-I MTsN 2 Kota Banjarmasin yang tergolong terampil berjumlah $10,71 \%$. Untuk peserta didik yang tergolong татри berjumlah 64,29\%. Peserta didik yang tergolong cukup terampil berjumlah 21,43\%. Peserta didik yang tergolong kurang terampil berjumlah $3,57 \%$.

\section{Saran}

Pada penelitian ini, sudah terdapat instrumen dan media dalam proses pembelajaran. Instrument dan media komik Doraemon yang sudah digunakan dapat menambah kreativitas peserta didik. Instrument dan media yang sudah diteliti diharapkan dapat diterapkan pada pembelajaran menulis cerita fantasi.

Bagi peneliti selanjutnya, apabila ingin meneliti keterampilan menulis cerita fantasi diharapkan meneliti dari aspek lainnya. Instrumen yang dipakai untuk menilai juga lebih banyak. Peserta didik yang diteliti diharapkan berbeda dan lebih luas/banyak lagi agar data yang diperoleh lebih bervariasi.

\section{DAFTAR RUJUKAN}

a. Dari Buku Teks

Dalman, H. 2016. Keterampilan Menulis. Depok: PT Rajagrafindo Persada.

Fujio, Fujiko. F. 2004. Cerita Spesial Doraemon Cerita Seram. Diterjemahkan dari bahasa Jepang oleh Sherry Suryo. Jakarta: PT Gramedia.

Harsiati, Titik, Agus Trianto dan E. Kosasih. 2017. Bahasa Indonesia SMP/MTs Kelas VII. Jakarta: Kementerian Pendidikan dan Kebudayaan.

McCloud, Scott. 2008. Memahami Komik. Diterjemahkan oleh S. Kinanti. Jakarta: Kepustakaan Populer Gramedia.

Nurgiyantoro. Burhan. 2013. Sastra Anak: Pengantar Pemahaman Dunia Anak. Yogyakarta: Gadjah Mada University Press.

Nurgiyantoro. Burhan. 2015. Teori Pengkajian Fiksi. Yogyakarta: Gadjah Mada University Press.

Rofi'uddin, Ahmad dan Darmiyati Zuhdi. 1999. Pendidikan Bahasa dan Sastra 
Indonesia di Kelas Tinggi. Jakarta: Dirjen Dikti Depdikbud.

Rukajat, Ajat. 2018. Penelitian Tindakan Kelas Classroom Action Research. Yogyakarta: Deepublish (Grup Penerbit CV Budi Utama)

Syafi'ie, I. 1988. Retorika dalam Menulis. Jakarta: Depdikbud.

Tarigan, Henry Guntur. 2013. Menulis: Sebagai Suatu Keterampilan Berbahasa. Bandung: Angkasa.

Waluyo, Budi. 2018. Bahasa dan Sastra Indonesia untuk Kelas VII SMP dan MTs. Solo: PT Tiga Serangkai Pustaka Mandiri Solo.

\section{b. Dari Skripsi/Tesis/Disertasi}

Aghittara, Amanda Oksaventa. 2016. Peningkatan Keterampilan Menulis Cerita Fiksi Melalui Metode Eksplorasi Membaca Siswa Kelas IVB di Sekolah Dasar Negeri Gedongkiwo Yogyakarta. Skripsi. Universitas Negeri Yogyakarta.

Nurazizah, Sifa. 2019 Kemampuan Menyusun Teks Eksplanasi dengan Media Kartu Bergambar Pada Peserta Didik Kelas VIII-D MTsN 2 Banjarmasin. Skripsi. Universitas Lambung Mangkurat.

Nurbaya. 2016. Efektivitas Penggunaan Media Komik dalam Pembelajaran Menulis Karangan Narasi Peserta Didik Kelas V MI Juluati Palulung Kecamatan Tombolo Pao Kabupaten Gowa. Skripsi. UIN Alauddin Makassar.

Rahman, Muhammad Aulia. 2019. Pemahaman Kosakata Bahasa Indonesia dalam Teks Deskripsi Pada Peserta Didik Kelas IX-D MTsN 2 Banjarmasin. Skripsi. Universitas Lambung Mangkurat.
Riyanti, Hestiana. 2017. Upaya Meningkatkan Kemampuan Menulis Cerita Fantasi Siswa Kelas VII SMP Negeri 3 Magelang Menggunakan Media Strip Story. Skripsi. Universitas Tidar.

\section{c. Dari Jurnal}

Ahmat, Jufri dan Wahyu Sukartiningsih. 2013. Penggunaan Media Komik untuk Meningkatkan Keterampilan Membaca Cerita di Kelas V Sekolah Dasar. Jurnal Penelitian Pendidikan Guru Sekolah Dasar, Vol. 1, No. 2.

Ain, Zamratul, dan Utami Dewi Pramesti. 2019. Korelasi Penggunaan Kosakata dengan Keterampilan Menulis Teks Cerita Fantasi Siswa Kelas VII SMP Negeri 16 Padang. Jurnal Pendidikan Bahasa dan Sastra Indonesia, Vol. 8, No. 1.

Batubara, Ahmad Fadhlin. 2013. Pemanfaatan Media Komik untuk Meningkatkan Kemampuan Menulis Cerpen Siswa Kelas X SMA Negeri 2 Kabanjahe. Jurnal Basastra, Vol. 1, No. 2.

Ezabella, Sriana, Edi Suyanto, dan Muhammad Fuad. 2014. Penggunaan Media Komik untuk Meningkatkan Kemampuan Menulis Naskah Drama Siswa. Jurnal J-Simbol (Bahasa, Sastra dan Pembelajarannya), Vol. 1, No. 2.

Gunawan, Gun Gun, Alvanov Z. Mansoor, Naomi Haswanto. 2016. Kajian Gaya Visual Storytelling Tatang Suhenra. Demandia, Vol. 1, No. 1.

Muslimin, Abdoel Gafar, dan Firman Tara. 2019. Peningkatan Kemampuan Menulis Cerita Fantasi Menggunakan Model Mind Mapping pada Siswa Kelas VII A SMP Negeri 24 Tanjung Jabung Timur Tahun Ajaran 
2018/2019. Aksara: Jurnal Ilmiah Pendidikan Bahasa dan Sastra Indonesia, Vol. 3, No. 1.

Nafisah, Durratun, Ida Lestari dan Yuni Pratiwi. 2012. Karakteistik Cerita Fantasi Anak Indonesia Periode 2000-2010. Jurnal Online UNM, Vol. 1, No. 1.

Putri, Weni Tria Anugrah. 2013. Penggunaan Media Film Kartun untuk Meningkatkan Keterampilan Menyimak Cerita di Sekolah Dasar. Jurnal Penelitian Guru Sekolah Dasar, Vol. 1, No. 2.

Saputra, Kadek Rudy, I Made Sutama, dan Gede Gunatama. 2017. Penggunaan Video Anak "Pertualangan Alice di Negeri Ajaib" untuk Meningkatkan Kemampuan Siswa Menulis Cerita Fantasi di Kelas VII H SMP Negeri 2 Sawan. E-Journal Jurusan Pendidikan Bahasa dan Sastra Indonesia Undiksha, Vol. 7, No. 2.

Siki, Ferdinandus, Sunoto dan Roekhan. 2017. Upaya Meningkatkan Kemampuan Menulis Cerpen Berdasarkan Pengalaman Pribadi dengan Strategi Pemodelan. Jurnal Pendidikan, Vol. 2, No. 12.

Waluyanto, H, D. 2005. Komik Sebagai Media Komunikasi Visual Pembelajaran. Jurnal Pendidikan, Vol. 7, No. 1.

\section{d. Dari Internet}

Effendy, Akip. 2015. Hakikat Keterampilan Menulis. Diakses tanggal 09 September 2019. https://www.kompasiana.com/akipeff endy/550eb183a33311b12dba83af/ha kikat-keterampilan-menulis.

Irwansyah, Ade. 2014. 7 Hari, Berapa Jumlah Penonton 'Stand By Me
Doraemon'?. Diakses tanggal 2 April 2019.

https://www.liputan6.com/showbiz/r ead/2148260/7-hari-berapa-jumlahpenonton-stand-by-me-doraemon.

Linggasari, Yohannie. 2014. 10 Pembelajaran Berharga dari Doraemon. Diakses tanggal 19 Februari 2020. https://www.cnnindonesia.com/hibur an/20141202094204-241-15174/10pembelajaran-berharga-daridoraemon.

Reza. 2018. 7 Museum yang Wajib Dikunjungi Penggemar Manga dan Komik di Jepang. Diakses tanggal 30 Oktober 2019. https://www.liputan6.com/lifestyle/r ead/3726364/7-museum-yang-wajibdikunjungi-pengemar-manga-dankomik-di-jepang. 